\title{
IMPACT OF DHAP RESIDUE ON THE PERFORMANCE OF SOME SELECTED WINTER VEGETABLES
}

\author{
Asit Baran \\ Mondal $^{1+}$ \\ Mohammad Bashir \\ Ahmed $^{2}$ \\ Md. Abdul Mannan
}

\author{
${ }^{\prime}$ Rural Reconstruction Foundation, Jashore, Bangladesh. \\ 'Email:mondalasit90@gmail.com Tel: +8801712577750 \\ ${ }^{2,3}$ Khulna University, Khulna, Bangladesh. \\ ${ }^{2}$ Email:mbaatku@gmail.com \\ ${ }^{s}$ Email:mannanku@gmail.com
}

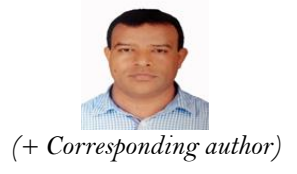

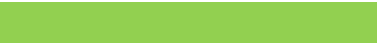

\section{Article History}

Received: 25 October 2021 Revised: 2 December 2021 Accepted: 20 December 2021 Published: 17 January 2022

\section{Keywords}

Floating garden Dhap residue

Nutrient sources

Vegetables production

Economic consideration.

\begin{abstract}
The experiment was conducted to evaluate the performance of dhap residue and nutrient sources on the growth and yield of red amaranth, radish and garlic during the period from October, 2013 to February 2014 and October, 2014 to February 2015 at Gopalganj district in Bangladesh. The single factor experiment was laid out in Randomized Complete Block Design (RCBD) with three replications. There were eight treatments viz. control (without organic and inorganic fertilizer), cowdung, recommended dose of NPK, $50 \%$ cowdung $+50 \%$ recommended dose of NPK, dhap residue, dhap residue + cowdung, dhap residue + recommended dose of NPK, dhap residue $+50 \%$ cowdung $+50 \%$ recommended dose of NPK. Dhap residue significantly influences the growth and yield of all three crops i.e red amaranth, radish and garlic. In respect of red amaranth, the tallest plant $(43.70 \mathrm{~cm}$ and $42.37 \mathrm{~cm}$, respectively) and maximum number of leaves (33.00 and 33.33, respectively) per plant as well as yield (20.88 and 21.32 t ha-1, respectively) were observed from dhap residue $+50 \%$ cow dung $+50 \%$ recommended dose of NPK which was significantly similar to dhap residue + recommended dose of NPK in both the years. Similar results were also observed in radish for root growth and in bulb production of garlic. From economic consideration, the application of dhap residue $+50 \%$ cow dung $+50 \%$ recommended dose of NPK fertilizers were suitable for growth and yield as well as cost effective for red amaranth, radish and garlic production under the climatic conditions in Gopalganj district of Bangladesh.
\end{abstract}

Contribution/Originality: This study is one of very few studies which have investigated the impact of dhap residue and cowdung along with NPK fertilizers for growth and yield as well as cost effective of some selected winter vegetables in Bangladesh. As a new concept, the study is original.

\section{INTRODUCTION}

Floating garden agricultural practices (locally known as Dhap) to grow vegetables and spices is prevailing in the wetlands of the south central coastal districts of Bangladesh from time immemorial, utilizing locally available water hyacinth (Eichhornia crassipes) and other aquatic weeds. The unique production system was developed in the hands of the locals by using their traditional knowledge for livelihood. The land with the water is used for production of fish in the open water and crops on the floating beds. Thus, ensures a sustainable utilization of agro biodiversity, natural resources and multiple use of the land. The bed materials are available locally free of cost. With the recession of water the beds touch the ground and winter crops are grown on the organic matter of the beds. The 
production system is almost organic. This is a low input and low cost resilient family farming production system. The system is sustainable and easily adaptable in similar flooded condition.

The floating platforms or rafts or floating beds were provides a base on the surface of water as the foundation of growing seedlings, vegetables and spices on it without soil. The plants grown on floating bed get nutrition and food either from composted organics or from the water. Decomposed water hyacinths are rich in a variety of organic debris and decomposing materials that release large amount of essential nutrients.

The floating beds that prepared during monsoon season there crops were grown. After harvesting the crops, in winter when the water recede and land exposed, the residual part of Dhaps were shifted and mixes the Dhap with the soil to enrich the soil fertility. The dried and rotten water hyacinths and other aquatic plants that act as composed manure or organic manure. This compost is very useful to both the plants and the soil. The land in which decomposed water hyacinth added need not use any other chemical fertilizers for sustains level of fertility of the soil. In this way, floating garden agricultural practice enhances eco-friendly agriculture practice in winter season to cultivate winter crops. Floating beds can be recycled as organic fertilizer in the newly prepared floating bed and also in the agricultural fields, which is economical as well as environmentally friendly (Saha, 2010).

The Dhap residue or decomposed water hyacinth can be applied directly to the soil. The compost increases soil fertility and crop yield and generally improves the quality of the soil. In developing countries where mineral fertilizer is expensive, it is an elegant solution to the problem of water hyacinth proliferation and also poor soil quality. It contains many trace elements, seldom found in synthetic fertilizers, so it helps plants to be more disease resistant. The nutrients are in the compost are not leached out by rainwater and all available to the plants (Vidya \& Girish, 2014).

Farmers cultivate in Dhap method traditionally and do not follow any Scientific method. So, it is necessary to find out a Scientific method or model for this purpose.

Considering the points in view, a study entitled as "Impact of Dhap Residue on the Performance of some Selected Winter Vegetables" was conducted with following objectives kept in mind.

\subsection{Objectives of the Research}

In view of the above cited facts, the present study was undertaken with the following objective:

1. To find out the impact of Dhap residue on the performance of some selected winter vegetables.

\section{MATERIALS AND METHODS}

\subsection{Experimental Design and Planting Materials}

The single factor experiment was conducted in Randomized Complete Block Design (RCBD) with three replications and with eight treatments viz. control (without organic and inorganic fertilizer), cowdung, recommended dose of NPK, $50 \%$ cowdung $+50 \%$ recommended dose of NPK, dhap residue, dhap residue + cowdung, dhap residue + recommended dose of NPK, dhap residue $+50 \%$ cowdung $+50 \%$ recommended dose of NPK and three crops viz. Red amaranth (Amaranthus gangaticus L.), Radish (Raphanus sativas. L) and Garlic (Allium sativum L.), seeds/bulbs were used as the planting materials in the experiment. The medium high land was prepared and the eight treatments were then distributed randomly among the each block so as to all treatments were placed once in each block. Afterwards $20 \mathrm{~kg}$ dhap residual spread (well decomposed water hyacinth that was used for vegetables production on floating condition in summer season) per plot and were mixed with soil with the help of a spade. The size of each unit plot was $2 \mathrm{~m} \times 1 \mathrm{~m}=2 \mathrm{~m}^{2}$.

\subsection{Seed Sowing and Planting}

Treated seeds of red amaranth, radish were sown and cloves of garlic were planted on first week of November 2013 and 2014 by maintaining spacing for specific crop. 


\subsection{Application of Manure and Fertilizers and Other Intercultural Operations}

Manure and fertilizers were applied according to the treatments considering by the FRG (2012). Irrigation, weeding, drainage, plant protection measures and other intercultural operations were done as and when necessary.

\subsection{Data Collection}

Five plants were selected randomly from each unit plot and the parameters were recorded at 15 days intervals including plant height $(\mathrm{cm})$, number of leaves plant $t^{-1}$, fresh weight of 5 plants $(\mathrm{g})$ and yield $\left(\mathrm{t} \mathrm{ha} \mathrm{a}^{-1}\right)$ in case of red amaranth, in respect of radish, number of leaves plant ${ }^{-1}$, length and diameter of root $(\mathrm{cm})$, root fresh weight $\left(\mathrm{g}\right.$ plant $\mathrm{t}^{-}$ ${ }^{1}$ ) and yield of root $\left(\mathrm{t} \mathrm{ha}^{-1}\right)$, in case of garlic, plant height $(\mathrm{cm})$, number of leaves plant $\mathrm{t}^{-1}$, length and diameter of bulb $(\mathrm{cm})$, individual bulb weight $(\mathrm{g})$, number of cloves bulb-1 and yield of bulb $\left(\mathrm{t} \mathrm{ha}^{-1}\right)$.

Recorded data were analyzed statistically with the help of computer package program MSTAT-C and the mean differences were adjudged by DUNCAN'S NEW MULTIPLE RANGE TEST (DMRT) at $5 \%$ level of probability for interpretation of the results (Gomez \& Gomez, 1984).

\section{RESULTS \& DISCUSSION}

Eight treatments viz. $\left(T_{1}\right)$ control (without organic and inorganic fertilizer), $\left(T_{2}\right)$ cowdung, $\left(T_{3}\right)$ recommended dose of NPK, $\left(\mathrm{T}_{4}\right) 50 \%$ cowdung $+50 \%$ recommended dose of NPK, $\left(\mathrm{T}_{5}\right)$ dhap residue, $\left(\mathrm{T}_{6}\right)$ dhap residue + cowdung, $\left(\mathrm{T}_{7}\right)$ dhap residue + recommended dose of NPK, $\left(\mathrm{T}_{8}\right)$ dhap residue $+50 \%$ cowdung $+50 \%$ recommended dose of NPK and crops of red amaranth, radish, and garlic were used for this study.

\subsection{Effects on Growth Parameters, Yield Components and Economic Consideration of Red Amaranth}

The impact of dhap residue and nutrient sources significantly influenced $(\mathrm{P} \leq 0.05)$ the growth parameters and yield of red amaranth Table 1. The tallest plant $(43.70$ and $42.37 \mathrm{~cm}$, respectively) and maximum number of leaves per plant (33.00 and 33.33, respectively) in 2013 and 2014 were recorded from $\left(\mathrm{T}_{8}\right)$ dhap residue $+50 \%$ cow dung + $50 \%$ recommended dose of NPK treatment while the shortest plant (16.03 and $16.87 \mathrm{~cm}$, respectively) and minimum number of leaves per plant (12.00 and 10.67, respectively) were found in $\left(T_{1}\right)$ control in 2013 and 2014. The highest yield (20.88 and $21.32 \mathrm{t} \mathrm{ha}^{-1}$, respectively) was obtained from $\left(\mathrm{T}_{8}\right)$ dhap residue $+50 \%$ cowdung $+50 \%$ recommended dose of NPK followed by $\left(\mathrm{T}_{7}\right)$ dhap residue + recommended dose of NPK (17.47 and 17.62 $\mathrm{t} \mathrm{ha}^{-1}$, respectively) and $\left(\mathrm{T}_{3}\right)$ recommended dose of NPK (12.96 and $12.77 \mathrm{t} \mathrm{ha}^{-1}$, respectively) where the lowest yield (5.03 and 5.04 t ha-1, respectively) was obtained from the $\left(T_{1}\right)$ control in 2013 and 2014. Fresh weight of 5 plants also followed the similar trend of results. Although fresh weight of 5 plants did not vary significantly in $\left(\mathrm{T}_{8}\right)$ dhap residue $+50 \%$ cowdung $+50 \%$ recommended dose of NPK and $\left(\mathrm{T}_{7}\right)$ dhap residue + recommended dose of NPK.

Table 1. Growth and yield contributing characters and yield of red amaranth as influenced by dhap residue and nutrient sources.

\begin{tabular}{|c|c|c|c|c|c|c|c|c|}
\hline \multirow{2}{*}{ Treatment } & \multicolumn{2}{|c|}{ Plant height $(\mathrm{cm})$} & \multicolumn{2}{|c|}{ Leaves plant ${ }^{-1}$ (No.) } & \multicolumn{2}{|c|}{ Fresh wt. of 5 plants $(\mathrm{g})$} & \multicolumn{2}{|c|}{ Yield $\left(\mathrm{t} \mathrm{ha} \mathrm{ha}^{-1}\right)$} \\
\hline & $1^{\text {st }} \mathrm{yr}$ & $2^{\text {nd }} \mathrm{yr}$ & $1^{\text {st }} \mathrm{yr}$ & $2^{\text {nd }} \mathrm{yr}$ & $1^{\text {st }} \mathrm{yr}$ & $2^{\text {nd }} \mathrm{yr}$ & $1^{\text {st }} \mathrm{yr}$ & $2^{\text {nd }} \mathrm{yr}$ \\
\hline $\mathrm{T}_{1}$ & $16.03 \mathrm{f}$ & $16.87 \mathrm{e}$ & $12.00 \mathrm{~d}$ & $10.67 \mathrm{e}$ & $5.47 \mathrm{f}$ & $5.27 \mathrm{e}$ & $5.03 \mathrm{f}$ & $5.04 \mathrm{f}$ \\
\hline $\mathrm{T}_{2}$ & $19.73 \mathrm{e}$ & $23.97 \mathrm{de}$ & $17.67 \mathrm{c}$ & $18.00 d$ & $12.67 \mathrm{e}$ & $13.07 \mathrm{~cd}$ & $7.67 \mathrm{e}$ & $7.55 \mathrm{e}$ \\
\hline $\mathrm{T}_{3}$ & $35.57 \mathrm{~b}$ & $34.73 \mathrm{~b}$ & $31.33 \mathrm{a}$ & $29.33 \mathrm{ab}$ & $23.27 \mathrm{~b}$ & $23.00 \mathrm{ab}$ & $12.96 \mathrm{c}$ & $12.77 \mathrm{c}$ \\
\hline $\mathrm{T}_{4}$ & $30.90 \mathrm{c}$ & $30.97 \mathrm{c}$ & $30.67 \mathrm{ab}$ & $28.33 \mathrm{~b}$ & $20.87 \mathrm{c}$ & $20.27 \mathrm{abc}$ & $11.15 \mathrm{~d}$ & $10.96 \mathrm{~cd}$ \\
\hline $\mathrm{T}_{5}$ & $17.97 \mathrm{ef}$ & $21.13 \mathrm{e}$ & $12.67 \mathrm{~d}$ & $11.33 \mathrm{e}$ & $7.73 \mathrm{df}$ & $8.27 \mathrm{de}$ & $7.56 \mathrm{e}$ & $7.14 \mathrm{e}$ \\
\hline $\mathrm{T}_{6}$ & $26.20 \mathrm{~d}$ & $25.00 d$ & $20.33 \mathrm{c}$ & $21.67 \mathrm{c}$ & $15.33 \mathrm{~d}$ & $16.53 \mathrm{bc}$ & $10.33 \mathrm{~d}$ & $10.70 \mathrm{~d}$ \\
\hline $\mathrm{T}_{7}$ & $40.40 \mathrm{a}$ & $37.07 \mathrm{~b}$ & $32.67 \mathrm{a}$ & $30.67 \mathrm{ab}$ & $25.80 \mathrm{a}$ & $24.27 \mathrm{a}$ & $17.47 \mathrm{~b}$ & $17.62 \mathrm{~b}$ \\
\hline $\mathrm{T}_{8}$ & $43.70 \mathrm{a}$ & $42.37 \mathrm{a}$ & $33.00 a$ & $33.33 \mathrm{a}$ & $28.00 a$ & $26.33 \mathrm{a}$ & $20.88 \mathrm{a}$ & $21.32 \mathrm{a}$ \\
\hline CV (\%) & 6.61 & 5.95 & 7.14 & 5.65 & 7.82 & 6.43 & 6.93 & 8.90 \\
\hline
\end{tabular}

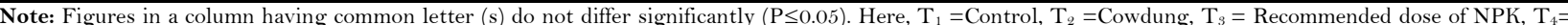
$50 \%$ cowdung $+50 \%$ Recommended dose of NPK, $\mathrm{T}_{5}=$ Dhap residue, $\mathrm{T}_{6}=$ Dhap residue + cowdung, $\mathrm{T}_{7}=$ Dhap residue + recommended dose of NPK, $\mathrm{T}_{8}=\mathrm{dhap}$ residue $+50 \%$ cowdung $+50 \%$ recommended dose of NPK. 
Plant height and number of leaves significantly increased by application of dhap residue and nutrient sources might be due to deeper root penetration and increased availability of nutrients. Dhap is supposed to be a good source of organic matter and when cowdung and fertilizers were applied especially nitrogenous fertilizer, the plant height and number of leaves increased significantly because nitrogen increases photosynthetic ability of the plant. Due to application of organic and inorganic fertilizers higher plant height in okra has been reported by Chattoo et al. (2011) and Malik, Chattoo, Sheemar, and Rashid (2011). Gayathri and Reddy (2013) also got the similar result.

In this study it was also revealed that dhap residue $+50 \%$ cowdung $+50 \%$ recommended dose of NPK produced the highest yield and it was probably due to the fact that combination of organic and inorganic fertilizers improved physical condition of the soil for better growth as well as supplied sufficient plant nutrients in all stages of plant growth. This result is in agreement with the findings of Mallanagouda, Sulikeri, Hulamari, Murthy, and Madalgeri (1995); Kropisz (1992); Vinay and Singh (1995).

\subsection{Economic Consideration}

Significant variations were found among the treatments in respect of the benefit cost ratio (BCR) Table 2. From the treatment $\left(\mathrm{T}_{8}\right)$ of dhap residue $+50 \%$ cowdung $+50 \%$ recommended dose of NPK showed the highest BCR (1.64) where the lowest BCR (0.57) value was found in the control( $\left.\mathrm{T}_{1}\right)$. The results revealed that dhap residue $+50 \%$ cowdung $+50 \%$ recommended dose of NPK was found to be suitable for higher economic return from red amaranth under the climatic conditions of Gopalganj.

Table 2. Cost and return analysis of red amaranth production due to impact of dhap residue in 2013 and 2014

\begin{tabular}{|c|c|c|c|c|c|}
\hline Treatment & $\begin{array}{c}\text { Mean } \\
\text { marketable } \\
\text { yield of two } \\
\text { years }(\mathrm{t} \mathrm{ha-1})\end{array}$ & $\begin{array}{l}\text { Mean total } \\
\text { variable cost of } \\
\text { two years } \\
\left.\text { ha }^{-1}\right)\end{array}$ & $\begin{array}{l}\text { Mean gross } \\
\text { return of } \\
\text { two years (t } \\
\left.\text { ha }^{-1}\right)\end{array}$ & $\begin{array}{l}\text { Mean net } \\
\text { return of } \\
\text { two years }(t \\
\left.\text { ha }^{-1}\right)\end{array}$ & $\begin{array}{c}\text { Mean benefit } \\
\text { cost ratio of } \\
\text { two years }(B C R)\end{array}$ \\
\hline $\mathrm{T}_{1}$ & $5.04 \mathrm{f}$ & $307400.00 \mathrm{e}$ & $176400.00 \mathrm{f}$ & $-131000 \mathrm{f}$ & $0.57 \mathrm{~g}$ \\
\hline $\mathrm{T}_{2}$ & $7.61 \mathrm{e}$ & $352216.67 \mathrm{~d}$ & $266350.00 \mathrm{e}$ & $-85866.67 \mathrm{e}$ & $0.76 \mathrm{f}$ \\
\hline $\mathrm{T}_{3}$ & $12.87 \mathrm{c}$ & $390266.67 \mathrm{c}$ & $450450.00 \mathrm{c}$ & $60183.33 \mathrm{c}$ & $1.15 \mathrm{c}$ \\
\hline $\mathrm{T}_{4}$ & $11.06 \mathrm{~d}$ & $367583.33 \mathrm{~cd}$ & $387100.00 \mathrm{~d}$ & $19516.67 \mathrm{~d}$ & $1.05 \mathrm{~d}$ \\
\hline $\mathrm{T}_{5}$ & $7.35 \mathrm{e}$ & $394416.67 \mathrm{c}$ & $257250.00 \mathrm{e}$ & $-137166.67 \mathrm{f}$ & $0.65 \mathrm{~g}$ \\
\hline $\mathrm{T}_{6}$ & $10.52 \mathrm{~d}$ & $435683.33 \mathrm{~b}$ & $368200.00 \mathrm{~d}$ & $-67483.33 \mathrm{e}$ & $0.85 \mathrm{e}$ \\
\hline $\mathrm{T}_{7}$ & $17.55 \mathrm{~b}$ & $473366.67 \mathrm{a}$ & $614250.00 \mathrm{~b}$ & $140883.33 \mathrm{~b}$ & $1.3 \mathrm{~b}$ \\
\hline $\mathrm{T}_{8}$ & $21.1 \mathrm{a}$ & $451633.33 \mathrm{ab}$ & $738500.00 \mathrm{a}$ & $286866.67 \mathrm{a}$ & $1.64 \mathrm{a}$ \\
\hline $\mathrm{CV}(\%)$ & 3.4 & 2.74 & 4.60 & 9.40 & 2.2 \\
\hline Level of significance & * & * & $*$ & $*$ & $*$ \\
\hline
\end{tabular}
Recommended dose of NPK, $\mathrm{T}_{4}=50 \%$ cowdung $+50 \%$ Recommended dose of NPK, $\mathrm{T}_{5}=$ Dhap residue, $\mathrm{T}_{6}=$ Dhap residue + cowdung, $\mathrm{T}_{7}=\mathrm{Dhap}$ residue + recommended dose of NPK, $\mathrm{T}_{8}=$ dhap residue $+50 \%$ cowdung $+50 \%$ recommended dose of NPK.

Sale of marketable red amaranth@ Tk.35000 per ton, Net return=Gross return - Total variable cost, Benefit cost ratio $(\mathrm{BCR})=$ Gross return $\div$ Total variable cost.

\subsection{Effects on Growth Parameters, Tield Components and Economic Consideration of Radish}

The impact of dhap residue, cowdung and fertilizers applications were significantly influenced $(\mathrm{P} \leq 0.05)$ the growth parameters and yield of radish Table 3. The maximum number of leaves per plant (23.67 and 23.00, respectively) was obtained from $\left(\mathrm{T}_{8}\right)$ dhap residue $+50 \%$ cowdung $+50 \%$ recommended dose of NPK followed by $\left(\mathrm{T}_{7}\right)$ dhap residue + recommended dose of NPK (21.67 and 21.33, respectively) and the minimum number of leaves per plant (10.67 and 10.67, respectively) was obtained from the control( $\left.\mathrm{T}_{1}\right)$ in 2013 and 2014. The longest root $(31.70$ and $33.13 \mathrm{~cm}$, respectively) and the maximum root diameter $(22.83$ and $23.40 \mathrm{~cm}$, respectively) were obtained from $\left(\mathrm{T}_{8}\right)$ dhap residue $+50 \%$ cowdung $+50 \%$ recommended dose of NPK followed by $\left(\mathrm{T}_{7}\right)$ dhap residue + recommended dose of NPK (29.57 and $30.77 \mathrm{~cm}$, respectively) and $(21.90$ and $21.20 \mathrm{~cm}$, respectively) whereas the 
shortest root length $(15.77$ and $16.73 \mathrm{~cm}$, respectively) and the minimum root diameter $(13.33$ and $12.70 \mathrm{~cm}$, respectively) were obtained from the $\operatorname{control}\left(\mathrm{T}_{1}\right)$ in 2013 and 2014. Dhap residue and nutrient sources influenced the yield of radish significantly. The maximum fresh weight of root (666.08 and $638.51 \mathrm{~g}$, respectively) and the highest root yield (91.67 and $90.48 \mathrm{t} \mathrm{ha}^{-1}$, respectively) were obtained from( $\left.\mathrm{T}_{8}\right)$ dhap residue $+50 \%$ cowdung + $50 \%$ recommended dose of NPK followed by $\left(\mathrm{T}_{7}\right)$ dhap residue + recommended dose of NPK (621.24 and 623.06 g, respectively) and (87.91 and $87.55 \mathrm{t} \mathrm{ha}^{-1}$, respectively) in 2013 and 2014 . In contrast, the minimum fresh weight of root per plant (115.44 and $105.29 \mathrm{~g}$, respectively) and the lowest root yield (28.78 and $27.62 \mathrm{t}^{-1}$, respectively) were obtained from the control $\left(\mathrm{T}_{1}\right)$ in 2013 and 2014.

Table 3. Growth and yield contributing characters and yield of radish as influenced by dhap residue and nutrient sources.

\begin{tabular}{|c|c|c|c|c|c|c|c|c|c|c|}
\hline \multirow[t]{2}{*}{ Treat. } & \multicolumn{2}{|c|}{$\begin{array}{c}\text { Leaves plant }{ }^{-1} \\
\text { (No.) }\end{array}$} & \multicolumn{2}{|c|}{ Root length $(\mathrm{cm})$} & \multicolumn{2}{|c|}{$\begin{array}{c}\text { Diameter of root } \\
(\mathrm{cm})\end{array}$} & \multicolumn{2}{|c|}{$\begin{array}{c}\text { Root fresh weight } \\
\left(\text { g plant }^{-1}\right)\end{array}$} & \multicolumn{2}{|c|}{ Yield $(\mathbf{t ~ h a - 1})$} \\
\hline & $1^{\text {st }} \mathrm{yr}$ & $2^{\text {nd }} \mathrm{yr}$ & $1^{\text {st }} \mathrm{yr}$ & $2^{\text {nd }}$ yr & $1^{\text {st }} \mathrm{yr}$ & $2^{\text {nd }} y \mathbf{y}$ & $1^{\text {st }} \mathrm{yr}$ & $2^{\text {nd }} \mathrm{yr}$ & $1^{\text {st }} \mathrm{yr}$ & $2^{\text {nd }} \mathrm{yr}$ \\
\hline $\mathrm{T}_{1}$ & $10.67 \mathrm{f}$ & $10.67 \mathrm{f}$ & $15.77 \mathrm{e}$ & $16.73 \mathrm{f}$ & $13.33 \mathrm{e}$ & $12.70 \mathrm{~g}$ & $115.44 \mathrm{e}$ & $105.29 \mathrm{~d}$ & $28.78 \mathrm{f}$ & $27.62 \mathrm{e}$ \\
\hline $\mathrm{T}_{2}$ & $15.00 \mathrm{e}$ & $15.33 \mathrm{e}$ & $19.60 d$ & $20.47 \mathrm{e}$ & $17.37 \mathrm{~d}$ & $15.13 \mathrm{f}$ & $245.22 \mathrm{~d}$ & $211.32 \mathrm{c}$ & $39.38 \mathrm{e}$ & $43.17 \mathrm{~d}$ \\
\hline $\mathrm{T}_{3}$ & $20.00 \mathrm{c}$ & $20.33 \mathrm{bc}$ & $28.53 \mathrm{~b}$ & $29.33 \mathrm{~b}$ & $20.70 b$ & $20.20 \mathrm{bc}$ & $496.17 \mathrm{~b}$ & $509.87 \mathrm{~b}$ & $69.21 \mathrm{~b}$ & $69.65 \mathrm{~b}$ \\
\hline $\mathrm{T}_{4}$ & $19.33 \mathrm{c}$ & $18.00 d$ & $26.70 \mathrm{c}$ & $27.43 \mathrm{c}$ & $19.10 \mathrm{c}$ & $18.57 \mathrm{~d}$ & $421.38 \mathrm{c}$ & $446.55 \mathrm{~b}$ & $64.87 \mathrm{~b}$ & $64.23 \mathrm{~b}$ \\
\hline $\mathrm{T}_{5}$ & $14.67 \mathrm{e}$ & $15.67 \mathrm{e}$ & $18.37 \mathrm{~d}$ & $20.67 \mathrm{e}$ & $16.50 \mathrm{Od}$ & $16.90 \mathrm{e}$ & $264.05 \mathrm{~d}$ & $219.12 \mathrm{c}$ & $46.19 \mathrm{~d}$ & $47.34 \mathrm{~d}$ \\
\hline $\mathrm{T}_{6}$ & $17.33 \mathrm{~d}$ & $18.67 \mathrm{~cd}$ & $24.90 \mathrm{c}$ & $25.23 \mathrm{~d}$ & $19.90 b c$ & $19.43 \mathrm{~cd}$ & $432.62 \mathrm{c}$ & $489.10 \mathrm{~b}$ & $54.25 \mathrm{c}$ & $54.72 \mathrm{c}$ \\
\hline $\mathrm{T}_{7}$ & $21.67 \mathrm{~b}$ & $21.33 \mathrm{ab}$ & $29.57 \mathrm{~b}$ & $30.77 \mathrm{~b}$ & $21.90 \mathrm{a}$ & $21.2 \mathrm{Ob}$ & $621.24 \mathrm{a}$ & $623.06 a$ & $87.91 \mathrm{a}$ & $87.55 \mathrm{a}$ \\
\hline $\mathrm{T}_{8}$ & $23.67 \mathrm{a}$ & $23.00 \mathrm{a}$ & $31.70 \mathrm{a}$ & $33.13 \mathrm{a}$ & $22.83 \mathrm{a}$ & $23.40 a$ & $666.08 \mathrm{a}$ & $638.51 \mathrm{a}$ & $91.67 \mathrm{a}$ & $90.48 \mathrm{a}$ \\
\hline $\mathrm{CV}(\%)$ & 7.73 & 7.39 & 6.10 & 5.32 & 7.11 & 7.60 & 9.44 & 10.10 & 8.25 & 8.69 \\
\hline
\end{tabular}

The maximum number of leaves per plant, root length, root diameter and yield of radish were produced to dhap residue $+50 \%$ cowdung $+50 \%$ recommended dose of NPK fertilizers due to dhap residue comparatively loose and supply adequate moisture and nutrients for higher vegetative growth and root easily penetrate in to the growing media and uptake required amount of nutrients. That might be reason for better results in dhap residue and combination of manure and fertilizers. The result was in conformity with the results of Pathak, Tripathi, Das, Sahu, and Pattanayak (2018) who reported that all the yield contributing characters and yield of radish was higher when organic and inorganic fertilizers were applied in combination than single. Similar results were obtained by Buckerfield, Flavel, Lee, and Webster (1999) in radish, Sood and Lal (2004) in potato, Singh, Pathak, Boopathi, and Deka (2010) and Bandani, Mobasser, and Sirusmehr (2014) in tomato and mung bean.

Table 4. Cost and return analysis of radish production due to impact of dhap residue in 2013 and 2014

\begin{tabular}{|c|c|c|c|c|c|}
\hline Treatment & $\begin{array}{c}\text { Mean } \\
\text { marketable } \\
\text { yield of two } \\
\text { years }\left(\mathrm{t} \mathrm{ha}^{-1}\right)\end{array}$ & $\begin{array}{c}\text { Mean total } \\
\text { variable cost } \\
\text { of two years } \\
(\mathrm{t} \mathrm{ha-1)}\end{array}$ & $\begin{array}{l}\text { Mean gross } \\
\text { return of two } \\
\text { years } \\
\left(\mathrm{t} \mathrm{ha}^{-1}\right)\end{array}$ & $\begin{array}{c}\text { Mean net } \\
\text { return of two } \\
\text { years }\left(\mathrm{tha}^{-1}\right)\end{array}$ & $\begin{array}{l}\text { Mean benefit } \\
\text { cost ratio of } \\
\text { two years } \\
(\mathrm{BCR})\end{array}$ \\
\hline $\mathrm{T}_{1}$ & $28.2 \mathrm{f}$ & $316183.33 \mathrm{f}$ & $282000.00 \mathrm{~g}$ & $-34183.33 \mathrm{f}$ & $0.89 \mathrm{e}$ \\
\hline $\mathrm{T}_{2}$ & $41.28 \mathrm{~d}$ & $361200.00 \mathrm{e}$ & $412800.00 \mathrm{f}$ & $51600.00 \mathrm{e}$ & $1.14 \mathrm{~d}$ \\
\hline $\mathrm{T}_{3}$ & $69.43 \mathrm{~b}$ & $407350.00 \mathrm{~cd}$ & $694300.00 \mathrm{~b}$ & $286950.00 \mathrm{c}$ & $1.70 \mathrm{c}$ \\
\hline $\mathrm{T}_{4}$ & $64.55 \mathrm{~b}$ & $376550.00 \mathrm{de}$ & $645500.00 \mathrm{c}$ & $268950.00 \mathrm{c}$ & $1.71 \mathrm{c}$ \\
\hline $\mathrm{T}_{5}$ & $46.77 \mathrm{e}$ & $400350.00 \mathrm{~d}$ & $467700.00 \mathrm{e}$ & $67350.00 \mathrm{e}$ & $1.17 \mathrm{~cd}$ \\
\hline $\mathrm{T}_{6}$ & $54.49 \mathrm{c}$ & $443833.33 \mathrm{bc}$ & $544900.00 \mathrm{~d}$ & $101066.67 \mathrm{~d}$ & $1.23 \mathrm{~d}$ \\
\hline $\mathrm{T}_{7}$ & $87.73 \mathrm{ab}$ & $487733.33 \mathrm{a}$ & $877300.00 \mathrm{a}$ & $389566.67 \mathrm{~b}$ & $1.80 \mathrm{~b}$ \\
\hline $\mathrm{T}_{8}$ & $91.08 \mathrm{a}$ & $479200.00 \mathrm{ab}$ & $910800.00 \mathrm{a}$ & $431600.00 \mathrm{a}$ & $1.90 \mathrm{a}$ \\
\hline $\mathrm{CV}(\%)$ & 4.2 & 3.32 & 2.64 & 4.44 & 2.98 \\
\hline Level of significance & * & * & * & * & * \\
\hline
\end{tabular}

Note: $*$ Significant at $5 \%$ level. Means followed by common letter(s) in a column do not differ significantly by DMRT. Here, $\mathrm{T}_{1}=$ Control, $\mathrm{T}_{2}=$ Cowdung, $\mathrm{T}_{3}=$ Recommended dose of NPK, $\mathrm{T}_{4}=50 \%$ cowdung $+50 \%$ Recommended dose of NPK, $\mathrm{T}_{5}=$ Dhap residue, $\mathrm{T}_{6}=$ Dhap residue + cowdung, $\mathrm{T}_{7}=$ Dhap residue + recommended dose of NPK, $\mathrm{T}_{8}=$ dhap residue $+50 \%$ cowdung $+50 \%$ recommended dose of NPK. 
Sale of marketable radish @ Tk.1000o per ton, Net return=Gross return - Total variable cost, Benefit cost ratio $(\mathrm{BCR})=$ Gross return $\div$ Total variable cost.

\subsection{Economic Consideration}

Significant variations were found among the treatments in respect of the benefit cost ratio (BCR) Table 4 . From the treatment $\left(\mathrm{T}_{8}\right)$ of dhap residue $+50 \%$ cowdung $+50 \%$ recommended dose of NPK showed the highest BCR (1.9) whereas the lowest BCR (0.89) value was found in the control( $\left.\mathrm{T}_{1}\right)$. The results revealed that dhap residue $+50 \%$ cowdung $+50 \%$ recommended dose of NPK was found to be suitable for higher economic return from radish under the climatic conditions of Gopalganj.

\subsection{Effects on Growth Parameters, Yield Components, Yield and Economic Consideration of Garlic}

The impact of dhap residue and nutrient sources were significantly influenced $(\mathrm{P} \leq 0.05)$ the growth parameters, yield components and yield of garlic Table 5. The tallest plant $(72.37$ and $74.17 \mathrm{~cm}$, respectively) and maximum number of leaves per plant (12.33 and 12.00, respectively) in 2013-14 and 2014-15 were achieved from ( $\left.\mathrm{T}_{8}\right)$ dhap residue $+50 \%$ cow dung $+50 \%$ recommended dose of NPK treatment whereas the shortest plant (45.07 and 49.80 $\mathrm{cm}$, respectively) and the minimum number of leaves per plant (6.00 and 5.67, respectively) were found in the control $\left(\mathrm{T}_{1}\right)$ in 2013-14 and 2014-15. The longest bulb length (6.33 and $6.33 \mathrm{~cm}$, respectively) and the maximum bulb diameter (17.83 and $17.40 \mathrm{~cm}$, respectively) were obtained from $\left(\mathrm{T}_{8}\right)$ dhap residue $+50 \%$ cowdung $+50 \%$ recommended dose of NPK whereas the shortest bulb length (3.53 and $4.27 \mathrm{~cm}$, respectively) and the minimum bulb diameter (9.23 and $11.90 \mathrm{~cm}$, respectively) were obtained from the control $\left(\mathrm{T}_{1}\right)$ in 2013-14 and 2014-15. The maximum bulb weight (61.33 and $59.80 \mathrm{~g}$, respectively) and maximum number of cloves per bulb (35.03 and 37.97 , respectively) were obtained from $\left(\mathrm{T}_{8}\right)$ dhap residue $+50 \%$ cowdung $+50 \%$ recommended dose of NPK whereas, the minimum bulb weight ( 15.20 and $21.63 \mathrm{~g}$, respectively) and the minimum number of cloves per bulb (14.53 and 14.90, respectively) was obtained from the control $\left(\mathrm{T}_{1}\right)$ in 2013-14 and 2014-15. The maximum yield (11.59 and $11.72 \mathrm{t} \mathrm{ha}^{-1}$, respectively) was obtained from $\left(\mathrm{T}_{8}\right)$ dhap residue $+50 \%$ cowdung $+50 \%$ recommended dose of NPK followed by $\left(\mathrm{T}_{7}\right)$ dhap residue + recommended dose of NPK (10.85 and $10.93 \mathrm{t} \mathrm{ha}^{-1}$, respectively) and $\left(\mathrm{T}_{6}\right)$ dhap residue + cowdung (8.78 and $8.94 \mathrm{t} \mathrm{ha}^{-1}$, respectively) and the minimum yield (3.16 and $3.56 \mathrm{t} \mathrm{ha}^{-1}$, respectively) was obtained from the control $\left(\mathrm{T}_{1}\right)$ in 2013-14 and 2014-15.

This might be due to the fact that dhap residue $+50 \%$ cowdung $+50 \%$ recommended dose of NPK kept the soil loose and both manure and fertilizers supplied adequate plant nutrients for better vegetative growth of garlic plants and ultimately increased bulb length and diameter as well as yield of garlic. The result was in conformity with the results of Chattoo et al. (2011) who obtained a higher plant height and leaf number per plant from organic + inorganic fertilizers in okra. Gayathri and Reddy (2013) and Malik et al. (2011) got the similar result in okra. Varu, Vhora, and Kikani (1997) obtained the highest bulb diameter from organic + inorganic fertilizers in onion. The plants received more nutrients when raised with the combination of organic and inorganic fertilizers.

\subsection{Economic Consideration}

Significant variations were found among the treatments in respect of the benefit cost ratio (BCR) Table 6 . From the treatment $\left(\mathrm{T}_{8}\right)$ of dhap residue $+50 \%$ cowdung $+50 \%$ recommended dose of NPK showed the highest BCR (1.79) whereas the lowest BCR (0.75) value was found in the control $\left(\mathrm{T}_{1}\right)$. The results revealed that dhap residue $+50 \%$ cowdung $+50 \%$ recommended dose of NPK was found to be suitable for higher economic return from garlic under the climatic conditions of Gopalganj. 
International Journal of Sustainable Agricultural Research, 2022, 9(1): 1-9

Table 5. Growth and yield contributing characters and yield of garlic as influenced by dhap residue and nutrient sources.

\begin{tabular}{|c|c|c|c|c|c|c|c|c|c|c|c|c|c|c|}
\hline \multirow[t]{2}{*}{ Treat. } & \multicolumn{2}{|c|}{ Plant height $(\mathrm{cm})$} & \multicolumn{2}{|c|}{$\begin{array}{l}\text { Leaves plant }^{-1} \\
\text { (No.) }\end{array}$} & \multicolumn{2}{|c|}{ Bulb length $(\mathrm{cm})$} & \multicolumn{2}{|c|}{$\begin{array}{l}\text { Diameter of bulb } \\
\text { (cm) }\end{array}$} & \multicolumn{2}{|c|}{$\begin{array}{l}\text { Individual bulb } \\
\text { weight (g) }\end{array}$} & \multicolumn{2}{|c|}{ No. of cloves bulb } & \multicolumn{2}{|c|}{$\begin{array}{c}\text { Yield of bulb } \\
\left(t \text { ha }^{-1}\right)\end{array}$} \\
\hline & $1^{\text {st }} \mathrm{yr}$ & $2^{\text {nd }} \mathrm{yr}$ & $1^{\text {st }} \mathrm{yr}$ & $2^{\text {nd }} \mathrm{yr}$ & $1^{\text {st }} \mathrm{yr}$ & $2^{\text {nd }} \mathrm{yr}$ & $1^{\text {st }} \mathrm{yr}$ & $2^{\text {nd }} \mathrm{yr}$ & $1^{\text {st }} \mathrm{yr}$ & $2^{\text {nd }} \mathrm{yr}$ & $1^{\text {st }} \mathrm{yr}$ & $2^{\text {nd }} \mathrm{yr}$ & $1^{\text {st }} \mathrm{yr}$ & $2^{\text {nd }} \mathrm{yr}$ \\
\hline $\mathrm{T}_{1}$ & $45.07 \mathrm{f}$ & $49.80 \mathrm{~d}$ & $6.00 \mathrm{e}$ & $5.67 \mathrm{f}$ & $3.53 \mathrm{~g}$ & $4.27 \mathrm{e}$ & $9.23 \mathrm{f}$ & $11.90 \mathrm{f}$ & $15.20 \mathrm{e}$ & $21.63 \mathrm{e}$ & $14.53 \mathrm{f}$ & $14.90 \mathrm{f}$ & $3.16 \mathrm{f}$ & $3.56 \mathrm{~g}$ \\
\hline $\mathrm{T}_{2}$ & $56.30 \mathrm{~d}$ & $56.53 \mathrm{c}$ & $8.00 \mathrm{~d}$ & $8.00 \mathrm{~d}$ & $5.17 \mathrm{e}$ & $5.07 \mathrm{~d}$ & $13.50 \mathrm{~d}$ & $14.07 \mathrm{~d}$ & $35.47 \mathrm{c}$ & $34.63 \mathrm{~d}$ & $20.03 \mathrm{e}$ & $20.93 \mathrm{e}$ & $5.14 \mathrm{e}$ & $5.38 \mathrm{f}$ \\
\hline $\mathrm{T}_{3}$ & $66.60 \mathrm{~b}$ & $65.47 \mathrm{~b}$ & $10.67 \mathrm{~b}$ & $10.67 \mathrm{~b}$ & $5.80 \mathrm{bc}$ & $5.87 \mathrm{bc}$ & $16.50 \mathrm{~b}$ & $16.17 \mathrm{~b}$ & $53.17 \mathrm{~b}$ & $52.83 \mathrm{~b}$ & $31.40 \mathrm{~b}$ & $30.43 \mathrm{c}$ & $7.72 \mathrm{c}$ & $7.87 \mathrm{~d}$ \\
\hline $\mathrm{T}_{4}$ & $61.53 \mathrm{c}$ & $63.57 \mathrm{~b}$ & $9.33 \mathrm{c}$ & $9.67 \mathrm{c}$ & $5.60 \mathrm{~cd}$ & $5.87 \mathrm{bc}$ & $15.47 \mathrm{bc}$ & $15.93 \mathrm{~b}$ & $52.13 \mathrm{~b}$ & $48.93 \mathrm{c}$ & $27.53 \mathrm{c}$ & $27.33 \mathrm{~cd}$ & $6.80 \mathrm{~d}$ & $7.15 \mathrm{de}$ \\
\hline $\mathrm{T}_{5}$ & $53.40 \mathrm{e}$ & $52.20 \mathrm{~cd}$ & $7.33 \mathrm{~d}$ & $7.00 \mathrm{e}$ & $4.33 \mathrm{f}$ & $5.23 \mathrm{~d}$ & $12.00 \mathrm{e}$ & $13.10 \mathrm{e}$ & $23.77 \mathrm{~d}$ & $32.90 \mathrm{~d}$ & $19.97 \mathrm{e}$ & $20.10 \mathrm{e}$ & $6.71 \mathrm{~d}$ & $6.58 \mathrm{e}$ \\
\hline $\mathrm{T}_{6}$ & $61.77 \mathrm{c}$ & $56.73 \mathrm{c}$ & $9.00 \mathrm{c}$ & $8.67 \mathrm{~d}$ & $5.30 \mathrm{de}$ & $5.67 \mathrm{c}$ & $14.47 \mathrm{~cd}$ & $15.13 \mathrm{c}$ & $40.47 \mathrm{c}$ & $48.70 \mathrm{c}$ & $25.50 \mathrm{~d}$ & $26.63 \mathrm{~d}$ & $8.78 \mathrm{~b}$ & $8.94 \mathrm{c}$ \\
\hline $\mathrm{T}_{7}$ & $68.80 \mathrm{~b}$ & $71.37 \mathrm{a}$ & $11.33 \mathrm{~b}$ & $11.33 \mathrm{ab}$ & $6.03 \mathrm{ab}$ & $5.97 \mathrm{~b}$ & $17.27 \mathrm{a}$ & $17.07 \mathrm{a}$ & $56.90 \mathrm{ab}$ & $55.07 \mathrm{~b}$ & $32.67 \mathrm{~b}$ & $33.97 \mathrm{~b}$ & $10.85 \mathrm{a}$ & $10.93 \mathrm{~b}$ \\
\hline $\mathrm{T}_{8}$ & $72.37 \mathrm{a}$ & $74.17 \mathrm{a}$ & $12.33 \mathrm{a}$ & $12.00 \mathrm{a}$ & $6.33 \mathrm{a}$ & $6.33 \mathrm{a}$ & $17.83 \mathrm{a}$ & $17.40 \mathrm{a}$ & $61.33 \mathrm{a}$ & $59.80 \mathrm{a}$ & $35.03 \mathrm{a}$ & $37.97 \mathrm{a}$ & $11.59 \mathrm{a}$ & $11.72 \mathrm{a}$ \\
\hline CV (\%) & 2.40 & 4.41 & 6.01 & 4.23 & 8.15 & 6.78 & 7.46 & 8.37 & 8.21 & 7.54 & 8.26 & 6.96 & 8.06 & 9.67 \\
\hline
\end{tabular}

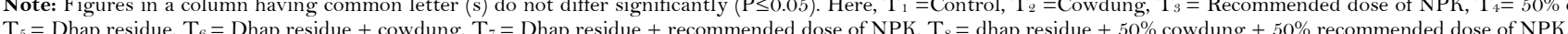


Table 6. Cost and return analysis of garlic production due to impact of dhap residue in 2013-14 and 2014-15.

\begin{tabular}{|c|c|c|c|c|c|}
\hline Treatment & $\begin{array}{c}\text { Mean } \\
\text { marketable } \\
\text { yield of two } \\
\text { years }\left(t \mathrm{ha}^{-1}\right)\end{array}$ & $\begin{array}{c}\text { Mean total } \\
\text { variable cost } \\
\text { of two years } \\
(\mathrm{t} \mathrm{ha-1})\end{array}$ & $\begin{array}{l}\text { Mean gross } \\
\text { return of two } \\
\text { years }\left(t \mathrm{ha}^{-1}\right)\end{array}$ & $\begin{array}{l}\text { Mean net } \\
\text { return of } \\
\text { two years } \\
(\mathrm{t} \mathrm{ha-1})\end{array}$ & $\begin{array}{c}\text { Mean benefit } \\
\text { cost ratio of } \\
\text { two years } \\
(\mathrm{BCR})\end{array}$ \\
\hline $\mathrm{T}_{1}$ & $3.36 \mathrm{f}$ & $358816.67 \mathrm{~d}$ & $268800.00 \mathrm{~g}$ & $-90016.67 \mathrm{~h}$ & $0.75 \mathrm{~g}$ \\
\hline $\mathrm{T}_{2}$ & $5.26 \mathrm{e}$ & $402466.67 \mathrm{~cd}$ & $420800.00 \mathrm{f}$ & $18333.33 \mathrm{~g}$ & $1.05 \mathrm{f}$ \\
\hline $\mathrm{T}_{3}$ & $7.8 \mathrm{c}$ & $447666.67 \mathrm{bc}$ & $624000.00 \mathrm{~d}$ & $176333.33 \mathrm{~d}$ & $1.39 \mathrm{~cd}$ \\
\hline $\mathrm{T}_{4}$ & $6.98 \mathrm{~d}$ & $420066.67 \mathrm{~cd}$ & $558400.00 \mathrm{e}$ & $138333.33 \mathrm{e}$ & $1.33 \mathrm{~d}$ \\
\hline $\mathrm{T}_{5}$ & $6.65 \mathrm{~d}$ & $445000.00 \mathrm{bc}$ & $532000.00 \mathrm{e}$ & $87000.00 \mathrm{f}$ & $1.20 \mathrm{e}$ \\
\hline $\mathrm{T}_{6}$ & $8.86 \mathrm{~b}$ & $486100.00 \mathrm{ab}$ & $708800.00 \mathrm{c}$ & $222700.00 \mathrm{c}$ & $1.46 \mathrm{c}$ \\
\hline $\mathrm{T}_{7}$ & $10.89 \mathrm{a}$ & $530833.33 \mathrm{a}$ & $871200.00 \mathrm{~b}$ & $340366.67 \mathrm{~b}$ & $1.64 \mathrm{~b}$ \\
\hline $\mathrm{T}_{8}$ & $11.66 \mathrm{a}$ & $521225.00 \mathrm{a}$ & $932800.00 \mathrm{a}$ & $411575.00 \mathrm{a}$ & $1.79 \mathrm{a}$ \\
\hline $\mathrm{CV}(\%)$ & 2.03 & 4.94 & 3.71 & 6.33 & 3.1 \\
\hline Level of significance & * & * & * & $*$ & * \\
\hline
\end{tabular}

Note: ${ }^{*}=$ Significant at $5 \%$ level. Means followed by common letter(s) in a column do not differ significantly by DMRT. Here, $\mathrm{T}_{1}=\mathrm{Control}, \mathrm{T}_{2}=$ Cowdung, $\mathrm{T}_{3}=$ Recommended dose of NPK, $\mathrm{T}_{4}=50 \%$ cowdung $+50 \%$ Recommended dose of NPK, $\mathrm{T}_{5}=$ Dhap residue, $\mathrm{T}_{6}=$ Dhap residue + cowdung, $\mathrm{T}_{7}=\mathrm{Dhap}$ residue + recommended dose of NPK, $\mathrm{T}_{8}=$ dhap residue $+50 \%$ cowdung $+50 \%$ recommended dose of NPK.

Sale of marketable garlic @ Tk.80000 per ton, Net return=Gross return - Total variable cost, Benefit cost ratio $(\mathrm{BCR})=$ Gross return $\div$ Total variable cost.

From the results of the experiment it was found that almost all the parameters studied were significantly influenced by dhap residue and nutrient sources. Almost all the characters attained the highest values when dhap residue $+50 \%$ cowdung $+50 \%$ recommended dose of NPK were applied. The control treatment gave the lowest values in all the characters in both the years (2013-14 and 2014-15, respectively). Dhap residue is supposed to be a good source of organic matter and when cowdung and fertilizers along with dhap residue were applied the studied parameters increased significantly and to be suitable for higher economic return from garlic under the climatic conditions of Gopalganj.

\section{CONCLUSION AND RECOMMENDATIONS}

Application of dhap residue $+50 \%$ cow dung $+50 \%$ recommended dose of NPK fertilizers were suitable for growth and yield as well as cost effective for red amaranth, radish and garlic production under the climatic conditions in Gopalganj district of Bangladesh.

Funding: This study received no specific financial support.

Competing Interests: The authors declare that they have no competing interests.

Authors' Contributions: All authors contributed equally to the conception and design of the study.

\section{REFERENCES}

Bandani, M., Mobasser, H. R., \& Sirusmehr, A. (2014). Effect of organic fertilizer on length of pod, biological yield and number of seeds per pod in mung bean (Vigna radiata L.). International Research Journal of Applied and Basic Sciences, 8(7), 763-766.

Buckerfield, J., Flavel, T., Lee, K., \& Webster, K. (1999). V earthworms and waste management-Vermicompost in solid and liquid forms as a plant-growth promoter. Pedobiologia, 43(6), 753-759.

Chattoo, M., Ahmed, N., Wani, M., Mir, S., Khan, S., \& Jabeen, N. (2011). Effect of organic manures and inorganic fertilizers on growth, yield and quality of Okra [Abelmochus esculentus (L.) Moench]. Vegetable Science, 38(2), 135-139.

FRG. (2012). Fertilizer recommendation guide (pp. 119-131). Farmgate, Dhaka, Bangladesh: Bangladesh Agricultural Research Council (BARC).

Gayathri, K., \& Reddy, P. (2013). Effect of integrated nutrient management growth and yield of okra (Abelmoschus esculentus (L). Moench) cv. Arka Anamika. Vegetable Science, 40(2), 246-248.

Gomez, K. A., \& Gomez, A. A. (1984). Statistical procedure for agricultural research (2nd ed., pp. 28-192). New York: John Willy and Sons. 
Kropisz, A. (1992). Influence of fertilization with compost on yield of vegetables and their content of mineral elements (Vol. 16, pp. 9-13). Horticulture: Annals of Warsaw Agricultural University.

Malik, A., Chattoo, M., Sheemar, G., \& Rashid, R. (2011). Growth, yield and fruit quality of sweet pepper hybrid SH-SP-5 (Capsicum annuum L.) as affected by integration of inorganic fertilizers and organic manures (FYM). Journal of Agricultural Technology, 7(4), 1037-1048.

Mallanagouda, B., Sulikeri, G. S., Hulamari, N. C., Murthy, B. G., \& Madalgeri, B. B. (1995). Effect of NPK and FYM on growth parameters of onion, garlic and coriander. Current Research University of Agricultural Sciences, India, 24(11), $212-213$.

Pathak, M., Tripathi, P., Das, S. K., Sahu, G. S., \& Pattanayak, S. K. (2018). Efficacy of biofertilizer, organic and inorganic fertilizer on yield and quality of radish (Raphanus sativus L.). International Journal of Chemical Studies, 6(4), 1671-1673.

Saha, S. K. (2010). Soil less cultivation for landless people: An alternative livelihood practice through indigenous hydroponic agriculture in flood-prone Bangladesh. Beppu: Ritsumeikan Asia Pacific University.

Singh, B., Pathak, K., Boopathi, T., \& Deka, B. (2010). Vermicompost and NPK fertilizer effects on morpho-physiological traits of plants, yield and quality of tomato fruits: (Solanum lycopersicum L.). Vegetable Crops Research Bulletin, 73(1), 77-86. Available at: https://doi.org/10.2478/v 10032-010-0020-0.

Sood, M. C., \& Lal, S. S. (2004). Evaluation of vermicompost as an organic source of plant nutrients in potato (Solanum tuberosum L.) (pp. 212-2 14). Lucknow, India: Organic Farming in Horticulture, CISH.

Varu, D., Vhora, P., \& Kikani, K. (1997). Effect of organic and inorganic fertilizers on onion. Gujarat Agricultural University Research Journal, 22(2), 116-118.

Vidya, S., \& Girish, L. (2014). Water hyacinth as a green manure for organic farming. International Journal of Research in Applied, Natural and Social Sciences, 2(6), 65-72.

Vinay, S., \& Singh, R. K. (1995). Response of onion (Allium cepa L) to N, P, Zn and FYM. Annals of Agricultural Research, 6(1), 79-81.

Views and opinions expressed in this article are the views and opinions of the author(s), International Journal of Sustainable Agricultural Research shall not be responsible or answerable for any loss, damage or liability etc. caused in relation to/arising out of the use of the content. 